\title{
Comparison of Methods of Acibenzolar-S-Methyl Application for Post-Infection Fire Blight Suppression in Pear and Apple
}

\author{
Kenneth B. Johnson and Todd N. Temple, Department of Botany and Plant Pathology, Oregon State University, Corvallis 97331-2902
}

\begin{abstract}
Johnson, K. B., and Temple, T. N. 2016. Comparison of methods of acibenzolar-S-methyl application for post-infection fire blight suppression in pear and apple. Plant Dis. 100:1125-1131.

Greenhouse-grown, 1-year-old potted 'Bosc' pear and apple rootstock cultivars 'M.9' and 'M.26' were inoculated with the fire blight pathogen, Erwinia amylovora, and subjected to trunk paint, root drench, or foliar spray treatments with acibenzolar-S-methyl (ASM, 4 to $30 \mathrm{mg}$ a.i./ tree) to induce systemic acquired resistance. Each method of ASM treatment suppressed fire blight canker expansion by 22 to $25 \%$. Furthermore, ASM application method and ASM treatment timing (at or \pm 3 weeks relative to inoculation) interacted significantly $(P \leq 0.02)$ in each experiment. A root drench was most effective when applied 3 weeks before inoculation (36\% suppression) whereas trunk paints and foliar sprays were more effective at inoculation (43 and $34 \%$,

suppression, respectively). Sizes of fire blight cankers in potted apple rootstocks M.9 and M.26 (under scions 'Gala' or 'Cameo') inoculated directly with the pathogen were reduced by 82 and $87 \%$ after two pretreatments of ASM applied as a trunk paint or root drench, respectively. Expression of pathogenesis-related (PR) genes PR-1 and - 2 in apple leaves sampled after an ASM trunk paint were elevated significantly $(P \leq 0.05)$ relative to control trees for at least 9 weeks after treatment. Results of this study are being used to guide field research on postinfection therapy with ASM in 1- to 10-year-old pear and apple trees where fire blight has proven difficult to manage with therapeutic pruning only.
\end{abstract}

Fire blight, caused by the bacterial pathogen Erwinia amylovora, can be severely damaging to pear and apple trees, especially in the first 1 to 10 years after orchard establishment. Ideally, orchardists prevent infection by the pathogen with protective sprays during primary bloom but, for various reasons, these treatments are not completely effective (Johnson and Stockwell 1998; Johnson and Temple 2013; Stockwell et al. 2008; Sundin et al. 2009). Once diseased, fire blight infections can expand quickly into running cankers in branches, scaffolds, or trunks, which require therapeutic pruning in late spring and early summer to remove the canker and limit damage to the tree (Johnson 2000; Steiner 2000). In older pear and apple trees ( $>10$ years), therapeutic pruning to remove fire-blight-infected tissues is generally effective at restoring tree health. In contrast, in younger trees, running cankers frequently reoccur at the site of the pruning cut owing to residual cells of the pathogen that become distributed in the xylem and intercellular spaces of parenchymal bark tissue of nonsymptomatic wood (Billing 2011; Bogs et al. 1998; Momol et al. 1998), even when the pruning cuts are made at a recommended distance (e.g., $30 \mathrm{~cm}$ ) below the proximal edge of the canker (Steiner 2000). This reincitement of disease leads to additional rounds of summer pruning and, potentially, to the death of the tree. Moreover, in apple, fire blight symptoms can reoccur near the graft union if a susceptible scion cultivar with a floral or shoot infection has been joined to an susceptible rootstock cultivar such as 'M.9' or 'M.26' (Norelli et al. 2003; van der Zwet and Beer 1992). This phase of the disease, termed rootstock blight, is also thought to be caused by the migration of residual pathogen cells through the xylem to the graft union (Momol et al. 1998) where, after reincitement of the disease, a girdling canker nearly always kills the tree (Momol et al. 1998; Norelli et al. 2003).

Research in the last few decades has demonstrated that many plant diseases can be suppressed by the induction of the host's

Corresponding author: K. Johnson;

E-mail: johnsonk@science.oregonstate.edu

Accepted for publication 13 December 2015.

http://dx.doi.org/10.1094/PDIS-09-15-1062-RE

(C) 2016 The American Phytopathological Society own defense mechanism, known as systemic acquired resistance (SAR) (An and Mou 2011; Fu and Dong 2013; Gozzo and Faoro 2013; Kessmann et al. 1994; Kuc and Richmond 1977; Sticher et al. 1997; van Loon et al. 2006). SAR is induced generally in response to both biotic and abiotic stresses, and its induction is regulated, at least in part, by the production of the signaling molecule salicylic acid. The signaling process leads to enhanced resistance to microbial infection and to the systemic accumulation of defense-related gene products termed pathogenesis-related (PR) proteins, which are hypothesized to contribute to the resistance response. Chemicals that mimic SAR-inducing properties of salicylic acid have been synthesized, of which acibenzolar-S-methyl (ASM) is now used as a foliar treatment in several crops for suppression of diseases caused by bacterial, fungal, and oomycete pathogens (Tally et al. 1999; Walters and Foutaine 2009; Walters et al. 2013).

SAR induction in fruit trees with ASM has been studied previously for the primary objective of preventing infection by canker-causing bacterial pathogens. Maxson-Stein et al. (2002) demonstrated that foliar sprays of ASM onto apple at high rates reduced the infection of flowers by E. amylovora, slowed canker expansion in a dosedependent manner, and induced expression of PR-1, -2 , and -8 . Recently, injection of ASM into xylem of apple trees reduced the incidence of floral and shoot infection by E. amylovora, and enhanced the expression of several PR genes (Aćimović et al. 2015). An ASM pot drench onto rooted Swingle citrumelo shoots (X Citroncirus spp.) provided several months of near-complete protection to foliar infection by the citrus canker pathogen Xanthomonas citri subsp. citri (Francis et al. 2009). This research group also observed partial suppression of citrus canker in a grapefruit orchard after soil drenches of ASM (Graham and Myers 2011) but not with foliar sprays of ASM (Graham and Leite 2004).

The purpose of this study was to make initial investigations into methods of ASM application that could potentially improve postinfection management of fire blight cankers in young pome fruit trees through the induction of SAR. Because well-managed commercial pear and apple orchards rarely show high incidences of fire blight (e.g., every tree), we were most interested in methods that could be implemented by orchard workers pruning out fire blight at the level of the sporadically distributed, individual diseased tree. Herein, we report effects of ASM applied as a root drench, trunk paint, or foliar 
spray onto greenhouse-grown, potted pear and apple trees diseased with fire blight.

\section{Materials and Methods}

Effect of ASM application method and timing on canker expansion. Greenhouse experiments were conducted in 2009 and 2011 with 1-year-old trees of 'Bosc' pear (15-mm caliper on OHxF.97 [2009] or OHxF.87 [2011] rootstocks; Pyrus communis L.) and in 2010 with apple rootstock M.26 (6.5-mm caliper) and 'M.9-Nic 29' (5-mm caliper) (Malus $\times$ domestica Borkh.). Each season, in March, dormant bare-root trees were received from commercial nurseries. Trees were planted during the last week of March or first week of April into 7.6-liter pots containing a peat, perlite, and pumice growth medium ( $\mathrm{pH}$ 5.6, Sunshine LA4 P; SunGro Horticulture, Agawam, $\mathrm{MA})$ and maintained in a greenhouse $\left(17\right.$ to $26^{\circ} \mathrm{C}$ with temperaturecontrolled venting and without supplemental lighting; from late May to early September, the greenhouse was hydrocooled and under $40 \%$ shade cloth). At planting, a heading cut was made to the main trunk at heights of $70 \mathrm{~cm}$ (apple rootstock cultivars) or $90 \mathrm{~cm}$ (Bosc pear) above the soil surface. After planting, trees were watered as needed and fertilized monthly with 20-10-20 Peter's Professional (Everris Inc., Marysville, $\mathrm{OH}$ ) at $0.5 \mathrm{~g} /$ pot supplemented with ammonium nitrate (Sigma-Aldrich, St. Louis) at $0.2 \mathrm{~g} /$ pot.

Fire blight was initiated by inoculation of a rapidly growing shoot with E. amylovora once in late spring (4 to 6 June). To inoculate the shoot, the meristematic tip and midveins on the two youngest leaves were split longitudinally with a surgical scissors to distances of 1 to $2 \mathrm{~cm}$ (Bogs et al. 1998; Ruz et al. 2008); wounded tissues were dipped into freeze-dried cells of E. amylovora strain Ea153 N resuspended in distilled water at a concentration of $1 \times 10^{9} \mathrm{CFU} / \mathrm{ml}$ (Stockwell et al. 1998). Immediately after inoculation, a zip-lock plastic bag $(16$ by $14 \mathrm{~cm})$ was fitted over each inoculated shoot with the locking edge sealed to within $1 \mathrm{~cm}$ of the stem. To ensure high humidity, 2 to $3 \mathrm{ml}$ of distilled water was syringed into each bag with a 30gauge needle inserted through the plastic side. Bags were removed after a 1-week incubation period.

Treatments of ASM (Actigard 50W; Syngenta Crop Protection, Greensboro, NC) included a root drench and foliar spray (all experiments) and trunk paint (2010 apple and 2011 pear experiments), with each application method split into three timings: 3 weeks prior to, at, and 3 weeks after the pathogen inoculation. Each experiment had one to two rates of ASM drenched into the potting medium, which ranged from 10 to $25 \mathrm{mg}$ of active ingredient (a.i.) in $500 \mathrm{ml}$ of water per pot; the rate of $25 \mathrm{mg}$ a.i./pot was represented in all experiments. A foliar spray of ASM was applied onto leaves to near runoff at rate of $250 \mathrm{mg}$ a.i./liter (Maxson-Stein et. al 2002). This created a variable dose depending on tree size and time of inoculation, which we estimated from weights of pre- and postsprayed foliage to be in the range of 4 to $12 \mathrm{mg} /$ plant. One to two paint treatments of ASM were applied with a flat foam brush $(5$ by $7 \mathrm{~cm}$, model 140-2; Solo Horton, Torrington, CT) to a $60-\mathrm{cm}$ length of woody trunk tissue, with the proximal edge of the treated area located just above the graft union (Bosc pear) or just above the soil-line (apple cultivars). Painted ASM concentrations were either 7.5 or $15 \mathrm{~g}$ a.i/liter suspended in distilled water plus $2 \%$ silicone surfactant (alkylphenol ethoxylate, polysiloxane polyether copolymer, and propylene glycol; Pentra-Bark; Quest Product Corp., Westminster, CO), which was added to aid penetration of ASM into the bark tissue (Garbelotto et al. 2007). Painting ASM onto tree trunks also created a variable dose dependent on trunk caliper. To estimate the dose of ASM painted onto each tree, preliminary experiments with treatment suspension retention on trunks provided the relationship $Y=0.0071 \cdot X$ $\left(R^{2}=0.92\right)$, where $Y$ is the mass of suspension retained (in grams) and $X$ is trunk surface area (in square centimeters) estimated from trunk caliper and length of treated trunk. Based on this relationship, an ASM paint prepared at a concentration of $15 \mathrm{~g}$ a.i/liter resulted in an approximate dose of 8.5, 15, and $30 \mathrm{mg}$ a.i./tree for M.9-Nic 29 and M.26 apple and Bosc pear, respectively. The experiments were arranged in a completely randomized design, with six replicate trees receiving the same ASM drench, paint, or spray treatment at each treatment timing. The inoculated, non-ASM-treated control was double replicated (12 trees); 6 trees were maintained as noninoculated, non-ASM-treated controls.

The dependent variable was the length of the resulting fire blight canker, which was measured in July, August, and September. When measuring cankers, a distinction was made between canker expansion in current-season vegetative tissue and canker expansion in woody trunk tissue produced the previous season. In addition, at the end of the 2009 and 2010 experiments, total shoot length on each tree was measured for the purpose of evaluating potential effects of the ASM treatment on plant growth.

ASM treatments were evaluated by averaging canker length of the final two disease assessments for each treated tree and dividing by the mean canker length of the final two disease assessments in the nontreated, inoculated control (12 trees comprised this mean). This ratio of relative canker length (\%) was subjected to two-way analysis of variance (ANOVA), with ASM treatment method as one factor and ASM treatment timing as the other (Analyze-it Software, Ltd., Leeds, UK). Relative canker length was plotted in graphical arrays as a function of ASM treatment timing; absolute canker length (in centimeters) was plotted in graphical arrays as a function of days from inoculation. Owing to a significant interaction among ASM treatment method and timing in each experiment, individual treatment means within each factor combination were compared with the expected value of the nontreated control with $t$ tests $\left(\mathrm{H}_{\mathrm{o}}\right.$ : relative canker length equals 1.0, rejected at $P \leq 0.05$ ). One-way ANOVA was performed on total shoot length data.

ASM protection of apple rootstocks under scions. The effect of prophylactic ASM treatments on fire blight canker size in apple rootstock trunk tissue just below the union with the scion was evaluated in greenhouse experiments. In 2010, plant material was 2-year-old rootstock M.26 under a 1-year-old 'Gala' scion; in 2011, experiments were conducted with rootstock M.26 and 'M.9-377' under a 'Cameo' scion. Trees were received in March from commercial nurseries in a bare-root condition and planted in late March into 11.4-liter pots using the same growth medium and greenhouse culture regime as described above. Trunk caliper of the rootstocks (aboveground portion) averaged $25 \mathrm{~mm}$, with 12-mm (Cameo) to 15-mm (Gala) trunk calipers for the scions.

One or two root drench or trunk paint treatments of ASM were applied to the trees. The first ASM treatment, made to all trees except nontreated controls, was applied 21 May 2010 and 26 May 2011; this timing approximated when blossom blight symptoms resulting from floral infection of the scion are typically first observed in pome fruit orchards located at northern latitudes. The second ASM treatment, applied to a subset of trees, occurred 4 to 6 weeks after the first treatment (2 July 2010 and 23 June 2011). Drench treatments of ASM were applied at a rate of $50 \mathrm{mg}$ a.i./pot in $500 \mathrm{ml}$ of water. Paint treatments of ASM (15 g a.i./liter in $2 \%$ Pentra-Bark) were applied with a foam brush to a sections of woody trunk tissue that extended $15 \mathrm{~cm}$ above and below the graft union. With the relationship of treatment suspension retention per unit of trunk surface area described above, the dose of ASM applied to trees was estimated to be 17 to $21 \mathrm{mg}$ a.i./tree. One additional paint treatment in each experiment utilized a half rate of ASM (7.5 g a.i/liter) at the second treatment timing.

Apple rootstocks were inoculated with E. amylovora on 8 July 2010 and 6 July 2011. Rootstock tissue was wounded by dragging the pointed ends of a bundle of three 9d-framing nails, held together tightly with a wrap of plastic electrical tape, from near the graft union downward toward the soil line. Wound dimensions were 6 to $7 \mathrm{~mm}$ wide and 60 to $80 \mathrm{~mm}$ in length; wounding depth was approximately $2 \mathrm{~mm}$, which extended into cambium but not into xylem. After wounding, the injured rootstocks were brushed with freeze-dried cells of Ea153 N resuspended at $1 \times 10^{7} \mathrm{CFU} / \mathrm{ml}$. Sheets of Parafilm M (10 by $20 \mathrm{~cm}$; Bemis Inc., Oshkosh, WI) were wrapped several times around the trunk to encase the inoculated wound; these wound wraps were removed at 15 (in 2010) or 20 (in 2011) days after inoculation. The experiment was arranged in a completely randomized design, with eight replicate trees receiving the same ASM drench or paint treatment. Four trees were maintained as noninoculated controls. 
After inoculation, trees were over-summered in the greenhouse (17 to $26^{\circ} \mathrm{C}$ under $40 \%$ shade cloth) and placed outside in midOctober to induce dormancy. Trees were returned to the greenhouse in mid-March 2011 (2010 experiment) and late January 2012 (2011 experiment). The dependent variable, fire blight canker area, was measured after the trees had broken winter dormancy and resumed growth (early May 2011 and early March 2012). To estimate canker area, height and width were measured (in centimeters) and converted to area, assuming an oval. A $5-\mathrm{cm}^{2}$ adjustment was subtracted from each estimated canker area to account for the bark tissue wounded by the nails prior to inoculation. Canker area was subjected to one-way ANOVA; treatment means were compared with the nontreated control with Fisher's protected least significant difference $(P \leq 0.05)$.

Effect of ASM application method on PR protein gene expression. Expression of PR genes was measured in potted, 1-year-old trees of apple scion Cameo (15-mm caliper trunk) on M.26 rootstock and Gala (12-mm caliper trunk) on 'M.7' rootstock after ASM root drench ( $25 \mathrm{mg}$ a.i./tree) or trunk paint (15 g a.i./liter to a $60-\mathrm{cm}$ length of trunk) treatments. Source of bare root trees, planting dates, growth medium, and greenhouse culture conditions were as described above. ASM treatments were applied to Cameo trees on 21 May and 20 June 2012 and to Gala trees on 29 May and 22 June 2015. The experiment was arranged in a completely randomized design, with four (in 2012) or eight (in 2015) replicate trees assigned to each ASM treatment method and to the nontreated control.

At 2, 5, and 9 weeks after the second ASM treatment ( 3 and 24 July and 20 Aug 2012, and 7 and 23 July and 26 Aug 2015, respectively), two leaves were sampled from each experimental tree in early morning and subjected to RNA extraction. Sampled leaves were fully expanded and of intermediate age relative to other leaves on the branch; the branch was located approximately $60 \mathrm{~cm}$ above the graft union. The two-leaf samples from each tree were subjected to RNA extraction following a lithium salts and acidified silica protocol. Briefly, leaves were ground using a mortar and pestle in $3 \mathrm{ml}$ of RNA extraction buffer consisting of $200 \mathrm{mM}$ Tris base, $300 \mathrm{mM} \mathrm{LiCl}$, $10 \mathrm{mM}$ EDTA, $1 \%$ sodium deoxycholate, $1.5 \%$ lithium dodecylsulfate, $1.43 \%$ NP-40, $\beta$-mercaptoethanol, and $0.1 \%$ diethyl pyrocarbonate (Maxson-Stein et al. 2002; Tzanetakis and Martin 2008). After grinding, the aqueous portion of the extraction mixture was decanted and treated with $6 \mathrm{M}$ potassium acetate $(1: 1)$ to precipitate polysaccharides. Following centrifugation $(10 \mathrm{~min}$ at $13,793 \times \mathrm{g})$, RNA was precipitated in isopropanol at $-80^{\circ} \mathrm{C}$ for $15 \mathrm{~min}$, centrifuged for $20 \mathrm{~min}$ to form a pellet, and bound to acidified silica ( $\mathrm{pH} 2.0$, silicon dioxide; Sigma-Aldrich). RNA on silica was washed three times with a solution of $10 \mathrm{mM}$ Tris-HCl, $0.5 \mathrm{mM}$ EDTA, and $5 \mathrm{M} \mathrm{NaCl}$, which was followed by a rinse for $1 \mathrm{~min}$ in $100 \%$ ethanol to remove phenolics and secondary metabolites. RNA was eluted from the silica in $0.01 \mathrm{M}$ Tris- $\mathrm{HCl}(\mathrm{pH} 8.5)$ and treated with DNase (Turbo DNA-free; Ambion Life Technologies Corp., Carlsbad, CA). RNA was visualized on a $1 \%$ agarose gel (70 V for $45 \mathrm{~min}$ ) and concentration was quantified using a NanoDrop spectrophotometer (ND-1000; Thermo Fisher Scientific Inc., Wilmington, DE). cDNA was synthesized from RNA (200 ng/ $\mu \mathrm{l})$ (First Strand Synthesis Kit; Thermo Fisher Scientific Inc.), then treated with RNase $\mathrm{H}$ (Thermo Fisher Scientific Inc.) at $37^{\circ} \mathrm{C}$ for 20 min. First-strand cDNA was cleaned in Buffer QG and Buffer PE (Qiagen Inc., Germantown, MD) on a mini-elute column (Epoch Life Sciences Inc., Sugarland, TX).

A 10-fold dilution of cDNA was mixed with iQ SYBR Green Supermix (Bio-Rad Inc., Hercules, CA) and with polymerase chain reaction (PCR) primers for apple genes actin (housekeeping gene), PR-1 (antifungal properties), PR-2 ( $\beta$-1,3-glucanase), or PR-8 (chitinase type III) (Maxson-Stein et al. 2002; Sinha et al. 2014). Levels of gene expression were measured with a quantitative real-time (qRT)PCR machine (model CFX96; Bio-Rad Inc.). Amplification protocol was $90^{\circ} \mathrm{C}$ for $5 \mathrm{~min}$., then 39 cycles of $90^{\circ} \mathrm{C}$ for $10 \mathrm{~s}$ and $58^{\circ} \mathrm{C}$ for $30 \mathrm{~s}$, followed by melt curve analysis $\left(95^{\circ} \mathrm{C}\right.$ for $10 \mathrm{~s}, 65^{\circ} \mathrm{C}$ for $5 \mathrm{~s}$, and $95^{\circ} \mathrm{C}$ for $50 \mathrm{~s}$ ) to verify single-gene amplification. Each leaf sample had three technical repetitions for each primer set. A subset of PCR products was sequenced and verified as the target genes.
From the qRT-PCR assays, cycle threshold $\left(\mathrm{C}_{\mathrm{t}}\right)$ values of technical replicates for each leaf sample were tabulated and averaged in a spreadsheet file. The Pfaffl equation (Pfaffl 2001) was used to calculate relative levels of gene expression for each biological replication: relative gene expression $=\left(\mathrm{E}_{\mathrm{target}}\right)^{\Delta \mathrm{Ct} \text { target(control-treated) }}$ $\left(\mathrm{E}_{\mathrm{ref}}\right)^{\Delta \mathrm{Ct} \text { ref(control-treated) }}$, where $\mathrm{C}_{\mathrm{t}}$ is the PCR cycle number at which fluorescence crosses the threshold; $\mathrm{E}_{\text {target }}$ is primer efficiency for target genes PR-1, PR-2, or PR-8; $\mathrm{E}_{\text {ref }}$ is the primer efficiency for the reference gene, actin; and $\Delta C_{t}$ is the difference in $C_{t}$ value of the gene being measured in the non-ASM-treated control minus the corresponding $\mathrm{C}_{\mathrm{t}}$ value measured from an ASM drench or paint treatment. $\log _{10^{-}}$ transformed means and standard errors of biological replicates were subjected to $t$ tests $\left(\mathrm{H}_{\mathrm{o}}: \log _{10}\right.$ [relative gene expression] $=0.0$, rejected at $P \leq 0.05$ ).

\section{Results}

Effect of ASM application method and timing on canker expansion. Each year, over the 9- to 10 -week period between planting and inoculation with E. amylovora, the dormant bare-root trees acquired for the study exhibited uniform leaf emergence and vegetative shoot production. At inoculation (4 to 6 June), lengths of the new shoots on the pear and apple trees were in the range of 30 to $50 \mathrm{~cm}$. Over all experiments, inoculation of a terminal shoot tip with E. amylovora incited fire blight in 196 of 198 trees (99\%); 2 pear trees in 2011 failed to develop an infection and were treated as missing values. In the first month after inoculation, for non-ASM-treated trees, the expanding canker consumed most of the vegetative shoot below the inoculation site (Fig. 1). From July to August, cankers in nonASM-treated trees continued to expand into the woody stem, where the rate of canker expansion slowed, especially in the apple rootstock cultivars (Fig. 1B) compared with Bosc pear (Fig. 1A). For Bosc pear, in both experiments, the canker on a few non-ASM-treated trees expanded to the graft union, killing the scion. In trees where fire blight canker expanded into the woody stem, secondary cankers frequently developed in noninoculated side shoots; these secondary cankers were not measured. The healthy, noninoculated control trees did not show fire blight symptoms.

Averaged over all experiments, ASM treatment suppressed fire blight canker expansion and reduced final canker lengths by 25 , 24 , and $22 \%$ when applied by root drench, trunk paint, and foliar spray, respectively. Statistically, however, the effects of ASM treatment timing and treatment method on canker length relative to the pathogen-inoculated, non-ASM-treated control interacted significantly in each experiment: $P \leq 0.002$ and 0.02 for Bosc pear in 2009 and 2011, respectively, and $P \leq 0.001$ for both apple rootstock experiments. In Bosc pear, the treatment timing-treatment method interaction resulted, at least in part, from the ASM root drench (25 mg a.i./pot) being most suppressive when applied 3 weeks prior to inoculation (mean over the 2009 and 2011 experiments was 53\% suppression of canker length) compared with other timings (Fig. 2A). In apple, root drench treatments resulted in reduced canker lengths for ASM timings of 3 weeks prior to and at inoculation but were ineffective when applied 3 weeks after inoculation (Fig. 2A). In contrast, for both pear and apple, ASM trunk paints (15 g a.i./liter) suppressed canker lengths significantly $(P \leq 0.05)$ when applied at inoculation (mean over all experiments was $43 \%$ canker suppression) but not when applied at the other timings (Fig. 2B). Effects of ASM foliar sprays were variable, with significant suppression $(P \leq 0.05)$ of canker lengths observed 3 weeks prior to inoculation in one experiment (M.9-Nic29), at inoculation in two experiments (Bosc pear 2009 and M.26 apple), and 3 weeks after inoculation in one experiment (Bosc pear 2009) (Fig. 2C). In the three experiments that evaluated two rates of ASM applied by the same method, when a significant reduction in relative canker length was observed, the trees that received the higher rate of ASM always had smaller cankers than the trees that received the lower rate (Fig. 2A,B). The raw data for the effect of ASM on fire blight canker expansion over time for two of the most suppressive combinations of treatment method by timing were compared with the nontreated control: root drench of $25 \mathrm{mg}$ a.i./pot applied 3 weeks prior to the pathogen inoculation of Bosc 
pear in 2009 (Fig. 1A) and trunk paint of $15 \mathrm{~g}$ a.i./liter applied at inoculation of M.26 apple in 2010 (Fig. 1B).

In 2010, relative to the non-ASM-treated, noninoculated control, total shoot lengths at the end of the experiments with M.26 and M.9-Nic29 were not affected significantly $(P>0.05)$ by the pathogen inoculation or by any of the ASM treatments (data not shown). For Bosc pear in 2009, treatments with numerous fire blight cankers on side shoots (the inoculated control and ASM-treated by spray or drench (10 $\mathrm{mg}$ a.i./pot) at 3 weeks prior to inoculation) showed significant reductions $(P \leq 0.05)$ in total shoot length compared with the non-ASM-treated, noninoculated control; in contrast, total shoot lengths for other ASM treatments were not significantly different $(P>0.05)$ from the non-ASM-treated, noninoculated control (data not shown). There were no visual symptoms of phytotoxicity from the any ASM treatments.

ASM protection of apple rootstocks under scions. As in the canker expansion experiments, each year the bare-root trees acquired for the study exhibited uniform growth during the spring and summer growing season, and no symptoms of phytotoxicity from the ASM trunk paint or root drench treatments were observed. At 2 to 3 weeks after inoculation, many of the trees exhibited signs of pathogen ooze leaking from under the Parafilm wound covering; noninoculated trees remained heathy. For the pathogen-inoculated controls, the overall success in initiating an expanding fire blight canker in the rootstock tissue was 100, 100, and 75\% for M.26/Gala, M.26/Cameo, and M.9-377/Cameo, respectively. For the M.9-377/Cameo experiment, the two inoculated control trees that did not develop a canker remained in the analysis because 37\% (14 of 40) of ASM-treated trees also failed to develop a canker.

Averaged over all experiments, after overwintering and spring leaf emergence, the fire blight canker completely encircled the rootstock

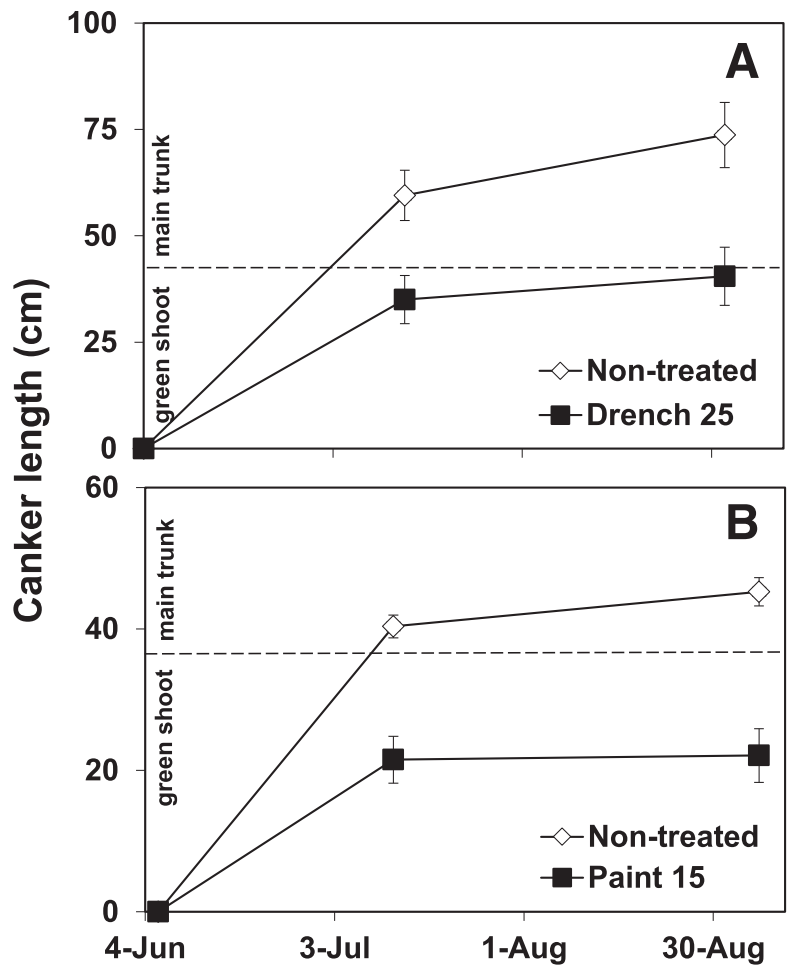

Fig. 1. Fire blight canker expansion over time as affected by acibenzolar-S-methyl (ASM) treatments applied to potted, 1-year-old pear and apple trees. In early June, a rapidly growing shoot tip was inoculated with Erwinia amylovora strain Ea153 N, and the resulting canker was allowed to expand down the shoot and trunk of the tree. A, Bosc pear in 2009 treated with ASM as a root drench $(25 \mathrm{mg}$ a.i./pot) 3 weeks prior to the pathogen inoculation $(\boldsymbol{\square})$ compared with the non-ASM-treated control $(\diamond)$. B, Apple rootstock M.26 in 2010 treated with ASM as a paint (15 g a.illiter in $2 \%$ silicone surfactant) applied to a $60-\mathrm{cm}$ length of trunk at the pathogen inoculation (compared with the non-ASM-treated control $(\diamond)$. Each point is the mean ( \pm standard error) of six trees. in $30 \%$ of inoculated control trees, $19 \%$ of trees receiving one ASM treatment, and $0 \%$ of trees receiving two ASM treatments. A significant effect of ASM treatment on canker size was observed in each of the experiments $(P \leq 0.001$ for M.26/Cameo in 2011, and $P \leq$ 0.05 for both M.26/Gala in 2010 and M.9-377/Cameo in 2011). In general, if a tree received either two ASM root drench treatments

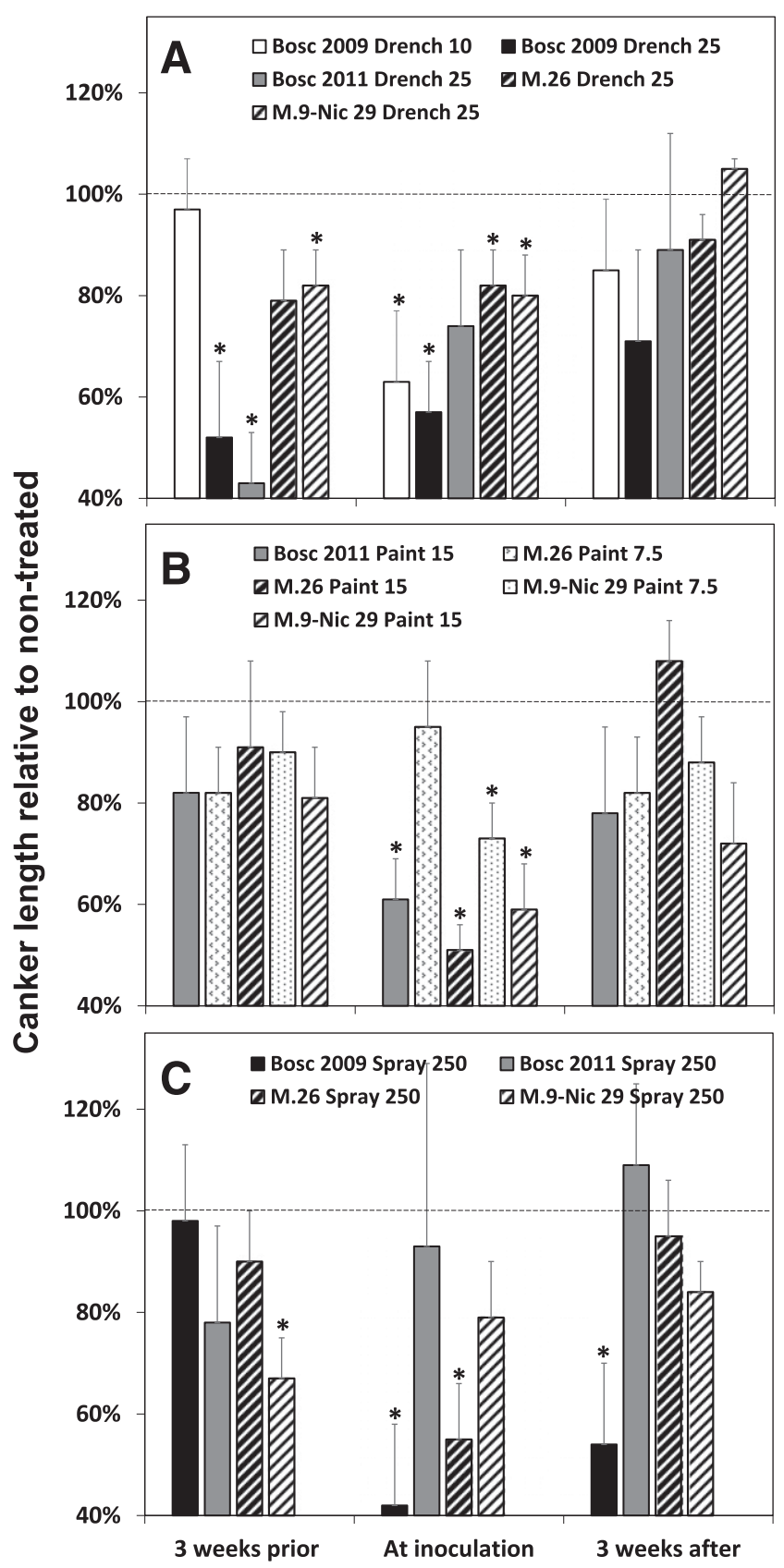

ASM treatment relative to pathogen inoculation

Fig. 2. Effect of acibenzolar-S-methyl (ASM) A, root drench; B, trunk paint; and C, foliar spray treatments applied to greenhouse-grown, potted, 1-year-old pear and apple trees to suppress fire blight canker expansion in four experiments conducted from 2009 to 2011. In each experiment, a rapidly growing shoot tip on each tree was inoculated with Erwinia amylovora strain Ea153 N in early June. Timings of single ASM treatments occurred 3 weeks prior to, at, or 3 weeks after the pathogen inoculation. Rates of ASM applied to trees were 10 or $25 \mathrm{mg}$ a.i. drenched onto the potting medium, 7.5 or $15 \mathrm{~g}$ a.i./liter in $2 \%$ silicone surfactant painted onto a $60-\mathrm{cm}$ length of trunk, and $250 \mathrm{mg}$ a.i./liter sprayed onto foliage to near runoff. Data are expressed as canker length on ASM-treated trees relative to the canker length on non-ASM-treated control trees. Smaller bars are the standard error of the mean $\left(n=6\right.$ trees). Asterisk $\left(^{*}\right)$ indicates that the null hypothesis $\left(H_{0}\right.$ : relative canker length equals 1.0 ) was rejected at $P \leq 0.05$. 
(50 mg a.i./pot) or two ASM trunk paint treatments (full rate of $15 \mathrm{~g}$ a. i./liter) prior to inoculation, then canker size in the rootstock was reduced significantly $(P \leq 0.05)$ by 78 to $92 \%$ compared with the nonASM-treated control (Fig. 3). For trees that received only one root drench of ASM, one trunk paint treatment of ASM, or one full rate trunk paint of ASM followed by a half-rate treatment, canker size reductions were variable, with only the M.26/Cameo experiment in 2011 showing consistent treatment effects from these intermediate doses of the SAR inducer (Fig. 3).

Effect of ASM application method on PR gene expression in apple leaves. For both experiments (M.26/Cameo in 2012 and M.7/Gala in 2015), compared with the untreated control, apple trees that received a trunk paint treatment of ASM in May and again in June showed significant induction $(P \leq 0.05)$ of PR-1 and PR-2 in all three apple leaf samples taken 13 to 57 days after the second ASM treatment (Fig. 4). Relative gene expression levels for PR-1 and PR-2 in trees that received a trunk paint of ASM ranged from 4- to 48-fold higher than in non-ASM-treated trees; expression of PR-8 ranged from 0- to 1.8-fold higher in the ASM paint treatment compared with non-ASM-treated trees. In contrast, although root drench treatments resulted generally in elevated levels of PR gene expression, significant induction $(P \leq 0.05)$ of PR-1 and PR-2 was observed only on the first sample (7 July) of the 2015 experiment.

\section{Discussion}

The goal of this study was to identify a method of ASM treatment that potentially could be adapted in pome fruit orchards as a therapy

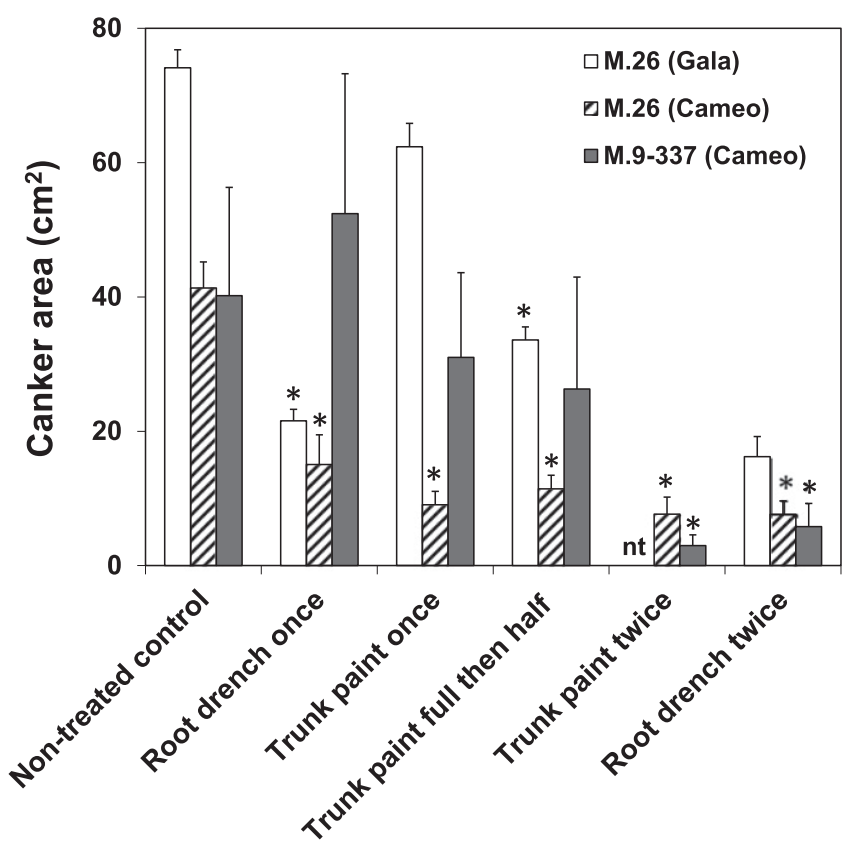

Fig. 3. Effect of acibenzolar-S-methyl (ASM) drench and trunk paint treatments applied prophylactically to greenhouse-grown, potted, 2-year-old apple rootstocks under 1-year-old scion cultivars to suppress fire blight canker expansion in the rootstock tissue below the graft union. In mid-July, the aboveground portion of the rootstock was wounded and inoculated with Erwinia amylovora strain Ea153 N. Timing of the first ASM treatments (all trees except the control) occurred in mid-May and the timing of the second ASM treatment, if applied, occurred in mid-June. For each treatment timing, the rates of ASM applied were $50 \mathrm{mg}$ a.i. drenched onto the potting medium or $15 \mathrm{~g}$ a.i./liter in $2 \%$ silicone surfactant painted onto a $60-\mathrm{cm}$ length of trunk; one paint treatment utilized an ASM rate of $7.5 \mathrm{~g}$ a.i./liter in $2 \%$ silicone surfactant at the second treatment timing. Final canker size was measured in March or May of the following season, after the trees had reinitiated growth after winter dormancy. Open bar: 2010 experiment with rootstock/scion cultivar combination M.26/Gala. Hatched and solid bars: 2011 experiments with rootstock/scion cultivar combinations M.26/Cameo and M.9-337/Cameo, respectively. Smaller bars are the standard error of the mean $\left(n=8\right.$ trees). Asterisk $\left(^{*}\right)$ indicates that the null hypothesis $\left(\mathrm{H}_{0}\right.$ : canker area of ASM-treated tree equals canker area of non-ASM-treated control) was rejected at $P \leq 0.05$. For the 2010 experiment, the "trunk paint twice" treatment was not tested (nt). to aid the restoration of tree health after fire blight infection. The need for an improved therapy arises because the current method of cutting cankers out of trees in late spring and early summer frequently fails to restore health, especially in the first 10 years after orchard establishment. In this regard, each of the methods we investigated in the greenhouse - root drench, trunk paint, and foliar spray - suppressed fire blight canker expansion in both pear and apple. The paint and drench methods applied prophylactically also protected apple rootstocks from girdling fire blight cankers after the pathogen was inoculated directly into this tissue. To our knowledge, this is the first published demonstration of fire blight canker expansion being affected by topical trunk paints or root drenches of ASM. Our data also confirm the result of Maxson-Stein et al. (2002), who demonstrated suppression of canker expansion through foliar sprays of ASM.

Previous studies of bacterial disease suppression with ASM applied to fruit trees have been concerned with prevention of infection (Aćimović et al. 2015; Brisset et al. 2000; Francis et al. 2009; Maxson-Stein et al. 2002) as opposed to its use as a therapy. Nonetheless, consistent among all of these studies has been the observation that fruit trees treated with ASM show increased expression of

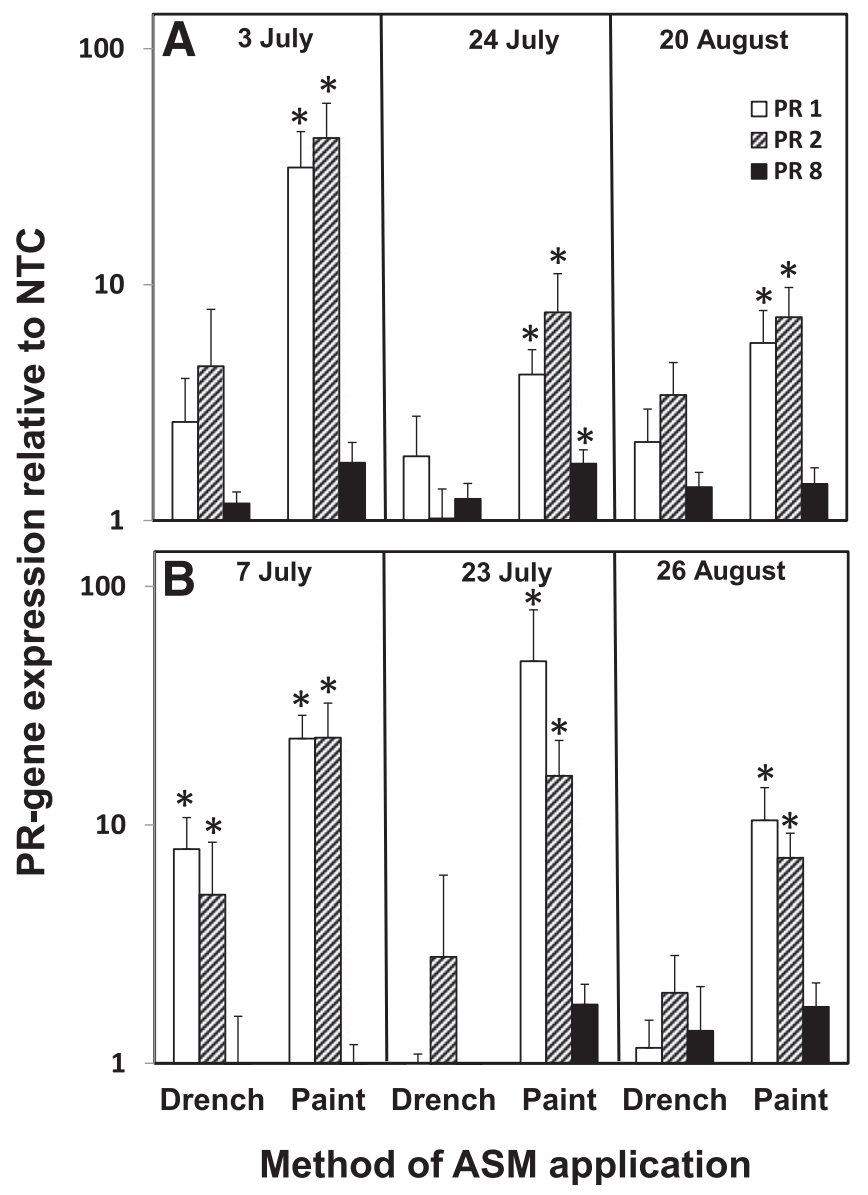

Fig. 4. Effect of acibenzolar-S-methyl (ASM) drench and trunk paint treatments applied to greenhouse-grown, potted, 1-year-old apple trees on expression of pathogenesisrelated (PR) genes PR-1, PR-2, and PR-8 in A, Cameo in 2012 and B, Gala in 2015 relative to the nontreated control (NTC). ASM was applied to the trees twice (except the NTC) with the first treatment occurring in mid-May and the second in mid-June. The rates of ASM applied were $25 \mathrm{mg}$ a.i. drenched onto the potting medium, or $15 \mathrm{~g}$ a.i./liter in $2 \%$ silicone surfactant painted onto a $60-\mathrm{cm}$ length of trunk, which deposited approximately $30 \mathrm{mg}$ of the material onto each tree. Relative levels of PR protein gene expression were quantified by quantitative reverse-transcription polymerase chain reaction performed on c-DNA prepared from total RNA extracts from apple leaves sampled approximately 2, 5, and 9 weeks after the second ASM treatment using actin as the reference gene. Asterisks $\left(^{*}\right)$ indicate that the null hypothesis $\left(H_{0}\right.$ : $\log _{10}$ [relative gene expression] $\left.=0\right)$ was rejected at $P \leq 0.05$. Data are plotted on a logarithmic scale; small bars denote the standard error for each mean. 
PR proteins in leaves (e.g., PR-1, -2, and -8), which are an indicator of SAR (Fu and Dong 2013; Kessmann et al. 1994; Sticher et al. 1997; van Loon et al. 2006). For PR-2, in particular, each of the studies cited above reported increased expression of this gene after treatment with ASM, although the methods of measuring induction, amount of ASM applied, and ages of plants differed among studies. Our results showed that trunk paints of ASM increased expression of PR-2 in leaves more than root drenches of this material, even though both methods of ASM application had consistent and comparable effects on fire blight canker expansion. In addition to application method, differences in rates of ASM applied or the proximity of the treated tissue (roots versus trunk) to the sampled leaves may have contributed to this difference in PR-2 induction. Compared with the earlier efforts, the increase in relative expression of PR-2 we observed with trunk paints of ASM ( 7 to $30 \mathrm{mg}$ per 1-year-old tree) was higher than observed by Aćimović et al. (2015) in mature apple trees trunk-injected with ASM (340 mg a.i. per 14- to 21-year-old trees) but less than observed by Maxson-Stein et al. (2002) with 4-week-old, vegetative apple seedlings sprayed with a high rate of ASM (1.5 g a.i./liter). With greenhouse-grown, rooted Swingle citrimelo shoots, Francis et al. (2009) demonstrated that expression of PR-2 was greatly enhanced by root drenches of ASM (5 mg a.i./pot) but not by foliar sprays of ASM (1 mg a.i./shoot). An important observation in citrimelo was elevated PR-2 expression for at least 27 weeks after an ASM root drench treatment. With ASM trunk paints, we measured enhanced expression of PR-2 for at least 9 weeks after treatment, which is a longer period than reported in other studies on apple (Aćimović et al. 2015; Brisset et al. 2000; Maxson-Stein et al. 2002).

As a potential therapy to utilize in a commercial pear or apple orchard, our data indicate that trunk (or branch) paints of ASM induce SAR for a prolonged period, place the material near where it is most needed on the tree, and potentially are adaptable to specific fire blight management situations in an orchard. In a well-managed orchard, fire blight cankers are commonly at low frequency and sporadically distributed, which requires orchard personnel to walk the tree rows and prune cankers as they are encountered. Based on our data, trunk paints were most effective at suppressing canker expansion when applied at the time of pathogen inoculation. Therefore, as an aid to pruning, this treatment could immediately induce SAR in the living cylinder of nonsymptomatic parenchyma and cambial tissues near the leading edge of the expanding canker (Billing 2011), especially if applied in conjunction with removal of diseased tissue. Personnel pruning fire blight cankers in commercial orchards also commonly use a disinfesting solution (e.g., bleach) to clean pruning tools between cuts and, therefore, could easily adopt the additional practice of painting a trunk or branch with ASM as cankers are removed. Note that we adopted the term "paint" to reflect a localized application of a concentrated rate of the material which, in this study, we applied onto trees with a foam brush. To facilitate a paint treatment at orchard scale, the suspension of ASM plus surfactant could be applied with an appropriately designed, hand-held sprayer.

The other methods of ASM treatment-root drench and foliar spray-showed potential for fire blight therapy but may encounter issues of scale due to the size of orchard-grown trees relative to 1-yearold trees in a greenhouse. From our data, root drenches were more effective when applied before pathogen inoculation compared with at or after inoculation and, potentially, this delay could be greater with larger trees growing in larger volumes of soil. Furthermore, rates of ASM effective as a therapy when applied to orchard soils are likely much higher than used in this study. For example, Graham and Myers (2011) successfully adapted a greenhouse observation (Francis et al. 2009) to achieve significant suppression of citrus canker with soil drenches of ASM in grapefruit orchards; however, amounts of material applied in the orchard were 40 to 160 times the amount of material applied in the greenhouse study. Tree size also may limit the efficiency and practicality of foliar sprays for personnel using hand-held sprayers and, with a tractor-pulled sprayer, the rate of ASM effective for therapeutic suppression could exceed the allowable amount that can be applied legally on a per-hectare basis. For example, the rate of ASM (250 mg a.i./liter) shown to suppress canker expansion by Maxson-Stein et al. (2002) in an orchard and by us in the greenhouse is approximately twice the labeled maximum rate of an ASM cover spray in pome fruit orchards (assuming 935 liters spray volume of water per hectare). This is not to say that ASM cover sprays will be unuseful in fire blight management because lower rates of this material have been shown to prevent initial infection by E. amylovora (Aćimović et al. 2015; Maxson-Stein et al. 2002) (K. Johnson, unpublished data). Furthermore, special situations such as tree nurseries could potentially adapt spray volumes or drip irrigation methods to utilize therapeutic rates of ASM in foliar or root drench treatments to aid restoration of nursery health after a fire blight outbreak.

Additional questions concerning therapeutic ASM treatments for fire blight suppression need to be evaluated with orchard-grown pear and apple trees. For example, for the paint treatment, we chose to amend ASM with a $2 \%$ solution of the silicone surfactant, PentraBark, owing to its previous use at this rate to aid infiltration of phosphite fungicides into cambium and outer xylem of oak trees for prevention and eradication of the sudden oak death pathogen, Phytophthora ramorum (Garbelotto et al. 2007). Although we did not observe phytotoxicity as a result of the ASM and Pentra-Bark paint treatment, determination of an optimal rate of surfactant should be evaluated in a field environment. In this context, how tree and bark tissue age affects the rate of surfactant required to infiltrate ASM requires further study. Second, in the apple rootstock/scion greenhouse experiment, two applications of ASM as trunk paint or root drench provided excellent suppression of canker development in rootstock tissue inoculated directly with the pathogen. From this result, we concluded that ASM was more effective if applied twice, which is consistent with early studies of SAR (Kuc and Richmond 1977) that demonstrated that the intensity of the resistance response was enhanced by a second (booster) treatment of the inducer. With the trunk paint treatment specifically, we also observed that reducing the rate of the second ASM treatment in the rootstock/scion experiment lessened the degree of suppression, which indicates that the response obtained from the SAR booster treatment is dose dependent. Both higher and lower doses of ASM paints applied to trunks and branches need to be studied in orchard-grown trees that have become diseased with fire blight via infection of the flowers as opposed to the highpathogen-dose wound inoculations that we utilized in the greenhouse environment.

\section{Acknowledgments}

Actigard 50W and Pentra-Bark surfactant were kindly provided by Syngenta Crop Protection, Greensboro, NC and Quest Products Corporation, Linwood, $\mathrm{KS}$, respectively. Technical assistance was provided by Oregon State University undergraduates L. Bauder, J. Coggins, M. Jackson, and E. Thomas. Partial funding was provided through grants from the Washington Tree Fruit Research Commission and the Pear Bureau Northwest's Fresh Pear Research Committee.

\section{Literature Cited}

Aćimović, S. G., Zeng, Q., McGhee, G. C., Sundin, G. W., and Wise, J. C. 2015. Control of fire blight (Erwinia amylovora) on apple trees with trunk-injected plant resistance inducers and antibiotics and assessment of induction of pathogenesis-related protein genes. Front. Plant Sci. 6:16.

An, C., and Mou, Z. 2011. Salicylic acid and its function in plant immunity. J. Integr. Plant Biol. 53:412-428.

Billing, E. 2011. Fire blight. Why do views on host invasion by Erwinia amylovora differ? Plant Pathol. 60:178-189.

Bogs, J., Bruchmüller, I., Erbar, C., and Geider, K. 1998. Colonization of host plants by the fire blight pathogen Erwinia amylovora marked with genes for bioluminescence and fluorescence. Phytopathology 88:416-421.

Brisset, M. N., Cesbron, S., Thomson, S. V., and Paulin, J. P. 2000. AcibenzolarS-methyl induces the accumulation of defence-related enzymes in apple and protects from fire blight. Eur. J. Plant Pathol. 106:529-536.

Francis, M., Redondo, A., Burns, J., and Graham, J. 2009. Soil application of imidacloprid and related SAR-inducing compounds produces effective and persistent control of citrus canker. Eur. J. Plant Pathol. 124:283-292.

Fu, D., and Dong, X. 2013. Systemic acquired resistance: Turning local infection into global defense. Annu. Rev. Phytopathol. 64:839-863.

Garbelotto, M., Schmidt, D. J., and Harnik, T. Y. 2007. Phosphite injections and bark application of phosphite + PentraBark ${ }^{\mathrm{TM}}$ control sudden oak death in coast live oak. Arboricult. Urban For. 33:309-317. 
Gozzo, F., and Faoro, F. 2013. Systemic acquired resistance (50 years after discovery): Moving from the lab to the field. J. Agric. Food Chem. 61: 12473-12491.

Graham, J. H., and Leite, R. P. 2004. Lack of control of citrus canker by induced systemic resistance compounds. Plant Dis. 88:745-750.

Graham, J. H., and Myers, M. E. 2011. Soil application of SAR inducers imidacloprid, thiamethoxam, and acibenzolar- $S$-methyl for citrus canker control in young grapefruit trees. Plant Dis. 95:725-728.

Johnson, K. B. 2000. Fire blight of apple and pear. Online publication. Plant Health Instruct. doi:10.1094/PHI-I-2000-0726-01

Johnson, K. B., and Stockwell, V. O. 1998. Management of fire blight: A case study in microbial ecology. Annu. Rev. Phytopathol. 36:227-248.

Johnson, K. B., and Temple, T. N. 2013. Evaluation of strategies for fire blight control in organic pome fruit without antibiotics. Plant Dis. 97:402-409.

Kessmann, H., Staub, T., Hofmann, C., Maetzke, T., Herzog, J., Ward, E., Uknes, S., and Ryals, J. 1994. Induction of systemic acquired disease resistance in plants by chemicals. Annu. Rev. Phytopathol. 32:439-459.

Kuc, J., and Richmond, S. 1977. Aspects of the protection of cucumber against Colletotrichum lagenarium by Colletotrichum lagenarium. Phytopathology 67:533-536.

Maxson-Stein, K., He, S.-Y., Hammerschmidt, R., and Jones, A. L. 2002. Effect of treating apple trees with acibenzolar-S-methyl on fire blight and expression of pathogenesis-related protein genes. Plant Dis. 86:785-790.

Momol, M. T., Norelli, J. L., Piccioni, D. E., Momol, E. A., Gustafson, H. L., Cummins, J. N., and Aldwinckle, H. S. 1998. Internal movement of Erwinia amylovora through symptomless apple scion tissues into the rootstock. Plant Dis. 82:646-650.

Norelli, J. L., Jones, A. L., and Aldwinckle, H. S. 2003. Fire blight management in the twenty-first century: Using new technologies that enhance host resistance in apple. Plant Dis. 87:756-765.

Pfaffl, M. W. 2001. A new mathematical model for relative quantification in realtime RT-PCR. Nucleic Acids Res. 29:e45.

Ruz, L., Moragrega, C., and Montesinos, E. 2008. Evaluation of four whole-plant inoculation methods to analyze the pathogenicity of Erwinia amylovora under quarantine conditions. Int. Microbiol. 11:111-119.
Sinha, M., Singh, R. P., Kushwaha, G. S., Iqbal, N., Singh, A., Kaushik, S., Kaur, P., Sharma, S., and Singh, T. P. 2014. Current overview of allergens of plant pathogenesis-related protein families. Sci. World J. Vol. 2014, Article ID 543195.

Steiner, P. W. 2000. Integrated orchard and nursery management for the control of fire blight. Pages 339-358 in: Fire Blight: The Disease and Its Causative Agent, Erwinia amylovora. J. L. Vanneste, ed. CAB International, London.

Sticher, L., Mauchmani, B., and Metraux, J. P. 1997. Systemic acquired resistance. Annu. Rev. Phytopathol. 35:235-270.

Stockwell, V. O., Johnson, K. B., and Loper, J. E. 1998. Establishment of bacterial antagonists of Erwinia amylovora on pear and apple blossoms as influenced by inoculum preparation. Phytopathology 88:506-513.

Stockwell, V. O., Temple, T. N., Johnson, K. B., and Loper, J. E. 2008. Integrated control of fire blight with antagonists and oxytetracycline. Acta Hortic. 793: 383-390.

Sundin, G. W., Werner, N. A., Yoder, K. S., and Aldwinckle, H. S. 2009. Field evaluation of biological control of fire blight in the eastern United States. Plant Dis. 93:386-394.

Tally, A., Oostendorp, M., Lawton, K., Staub, T., and Bassi, B. 1999. Commercial development of elicitors of induced resistance to pathogens. Pages 357-370 in: Induced Plant Defenses Against Pathogens and Herbivores: Biochemistry, Ecology, and Agriculture. A. A. Agrawal, S. Tuzun, and E. Bent, eds. American Phytopathological Society, St. Paul, MN.

Tzanetakis, I. E., and Martin, R. R. 2008. A new method for extraction of doublestranded RNA from plants. J. Virol. Methods 149:167-170.

van der Zwet, T., and Beer, S. V. 1992. Fire Blight-Its Nature, Prevention, and Control: A Practical Guide to Disease Management. Agric. Inf. Bull. 613 USDA Science and Education Administration, Washington, DC.

van Loon, L. C., Rep, M., and Pieterse, C. M. J. 2006. Significance of inducible defense-related proteins in infected plants. Annu. Rev. Phytopathol. 44:135-162.

Walters, D. R., and Foutaine, J. M. 2009. Practical application of induced resistance to plant diseases: An appraisal of effectiveness under field conditions. J. Agric. Sci. 147:523-535.

Walters, D. R., Ratsep, J., and Havis, N. D. 2013. Controlling crop diseases using induced resistance: Challenges for the future. J. Exp. Bot. 64:1263-1280. 